\title{
Electrophysiological studies of the action of gonadotropins on Leydig and Sertoli cells from rat testis
}

\author{
M. JOFFRE, Annick ROCHE, P. DUCHATELLE \\ with the technical assistance of Pierrette REGONDAUD
}

Laboratoire de Physiologie Animale, C.N.R.S., UA 290 Biomembranes,

UER Sciences, 40, avenue Recteur-Pineau, F 86022 Poitiers Cedex. France.

Summary. Using intracellular microelectrode recordings, it was observed that FSH caused the hyperpolarization of cultured Sertoli cells from the testis of 17-day old rats; this hyperpolarization was related to the activation of a $\mathrm{Na} / \mathrm{K}$ pump and an increase in $\mathrm{Na} / \mathrm{Ca}$ influx and $\mathrm{K}$ efflux. The effect was irreversible and mediated by cAMP. Some other results suggested an initial effect of FSH on the junctional complex between the Sertoli cells and then its calcium dependence.

Voltage-clamped membrane currents were investigated from whole-cell patch clamp recordings performed on single Leydig cells isolated from adult rat testis. Two outward currents were evoked by depolarizing voltage steps : a potassium current recorded in cells dialyzed with low-calcium media $\left(10^{-9}-10^{-8} \mathrm{M}\right)$ and a chloride current recorded in cells dialyzed with high-calcium media $\left(10^{-7}-10^{-6} \mathrm{M}\right)$. These responses to modifications of intracellular calcium were not affected by hCG. However, this hormone induced an early change of the $\mathrm{K}$ current to a $\mathrm{Cl}$ current when the cells were dialyzed by a low-buffered EGTA-calcium medium.

These results suggest that hCG stimulation involved the blockade of a potassium current and the activation of a chloride current through an increase of intracellular calcium.

\section{Introduction.}

A number of biochemical studies have contributed to elucidate the intracellular mechanisms involved in the stimulus-secretory coupling of Leydig and Sertoli cells by gonadotropins (Saez et al., 1985). Luteinizing hormone (LH) and human chorionic gonadotropin ( $\mathrm{hCG}$ ) act directly on Leydig cells, while follicle-stimulating hormone (FSH) acts directly on Sertoli cells. There is general agreement that these three gonadotropins bind to membrane receptors and increase adenyl cyclase activities in their respective targets.

In many secretory cells electrophysiology has yielded results on ion transport across the membrane of the cells and showed that changes in membrane properties are involved in hormone stimulation (see reviews: Petersen, 1980; Poisner and Trifaró, 1985; Ozawa and Sand, 1986). 
With the exception of an article by Cuthberg and Wong (1975) on Sertoli cells, no electrical investigations have been carried out in the endocrine and exocrine cells from testis. In an attempt to obtain information on the mechanisms of stimulation by gonadotropins, we applied intracellular microelectrode and patch clamp techniques to Leydig and Sertoli cells isolated from rat testis.

\section{Material and methods.}

Sertoli cell preparations. - Sertoli cells were isolated from testes of 17-day old Wistar rats by an incubation in presence of collagenase (Boehringer, Mannheim), followed by a second treatment using pancreatin (Sigma) according to Verhoeven, Dierickx and De Moor (1979). The final cell preparations were cultured in RPMI medium (Flow). They were stimulated with ovine FSH (NIAMDD S $_{15}$ and $\mathrm{S}_{16}$ ) prior to or during electrophysiological measurement.

Leydig cell preparations. - Leydig cells were isolated from adult Wistar rat testes by an incubation in presence of collagenase (Borhringer, Mannheim) according to Joffre et al. (1984a), followed by purification through a discontinuous gradient of Percoll ( $R$ ). The cells were plated either on plastic petri dishes previously coated with collagen for a short period of incubation (1-6h) or directly on the plastic for a longer period (up to $30 \mathrm{~h}$ ). Cells were cultured in RPMI medium (Flow) with fetal calf serum (Gibco, $1 \%$ ). They were used either directly or stimulated with hCG (Organon) prior to or during measurement.

Intracellular recording. - Intracellular recordings of membrane potential and resistance were performed, with the method described elsewhere in detail (Joffre et al., 1984a), on single Leydig cells (short incubation : 1-6 h) and on Sertoli cells (day 3 of culture onwards).

The standard bathing solution employed for recording was Earle's solution $(\mathrm{mM}): 116.5 \mathrm{NaCl} ; 5.4 \mathrm{KCl} ; 1.8 \mathrm{CaCl}_{2} ; 0.8 \mathrm{MgSO}_{4} ; 0.9 \mathrm{NaPO}_{4} \mathrm{H}_{2} ; 10$ glucose ; 5 HEPES- $\mathrm{NaOH}(\mathrm{pH}: 7.2)$.

Patch clamp recording. - - Patch clamp experiments were performed on single cells using whole-cell recording and outside-out configurations (Sakmann and Neher, 1983). This method was applied to Leydig cells by Duchatelle and Joffre (1987). The standard extracellular solution contained $(\mathrm{mM}): 140 \mathrm{NaCl} ; 5 \mathrm{KCl}$; $2 \mathrm{CaCl}_{2} ; 1 \mathrm{MgCl}_{2}$; 10 glucose ; 5 HEPES-NaOH (pH: 7.2), while pipette internal solution was $(\mathrm{mM}): \mathrm{KCl}$ (added at a concentration so that internal concentration was 150$) ; 1 \mathrm{MgCl}_{2} ; 10$ HEPES-KOH ( $\left.\mathrm{pH}: 7.2\right)$. This internal solution contained EGTA and $\mathrm{CaCl}_{2}$ to buffer intracellular free calcium in the concentration range of $10^{-9}-10^{-6} \mathrm{M}$ (see legends). To study the $\mathrm{Cl}$ channel, the internal and external solutions were modified to move $\mathrm{E}_{\mathrm{C} 1}$ by replacing $\mathrm{NaCl}$ with equimolar $\mathrm{Na}$-glutamate.

\section{Results and discussion.}

Effects of FSH on immature Sertoli cells from rat testis in monolayer culture.

After 2 days of culture, most Sertoli cells attached to the Petri dish and flattened out, forming a cell monolayer. Some germ cells were also present, but 
they did not attach to the culture dish and were largely eliminated when the culture medium was changed.

Because of the increase in microelectrode resistance, which occurred throughout the recordings, and the contraction of the cells under FSH stimulation which destroyed their stability of impalement, it was never possible to measure changes in the membrane potential of a same single cell progressively exposed to FSH. So, membrane potential values were determined on two lots: unstimulated cells $(n=300)$ and FSH-stimulated cells $(n=310)$.

Neither unstimulated nor FSH-stimulated cells triggered action potentials spontaneously or after the application of a depolarizing pulse, showing that the Sertoli cells (as all exocrine cells) were not excitable.

Ovine FSH induced Sertoli cell hyperpolarization and it was dose-dependent. An increase in the $\mathrm{FSH}$ concentration from 0 to $5.9 \mu \mathrm{g} / \mathrm{ml}$ allowed the membrane potential to rise from $-21.6 \pm 0.3 \mathrm{mV}(\mathrm{n}=300)$ to $-37.0 \pm 0.2 \mathrm{mV}(\mathrm{n}=310)$ (Joffre and Roche, 1988). This increase occurred with rats of all ages (from 7 to 37 days old) and was never reversed by the removal of $\mathrm{FSH}$, either by cell incubation for 24 to $72 \mathrm{~h}$ in a hormone-free medium (fig. 1) or by cell washing with a low pH glycine buffer $\left(\mathrm{pH}=3\right.$ ) at $4{ }^{\circ} \mathrm{C}$ (Bernier and Saez, 1985 ; Roche and Joffre, 1988). This hyperpolarization was specific to FSH since hCG did not alter the membrane potential and was mediated through cAMP, i.e. $1 \mathrm{mM}$ dBCAMP produces a similar decrease of membrane potential (Joffre and Roche, 1988).

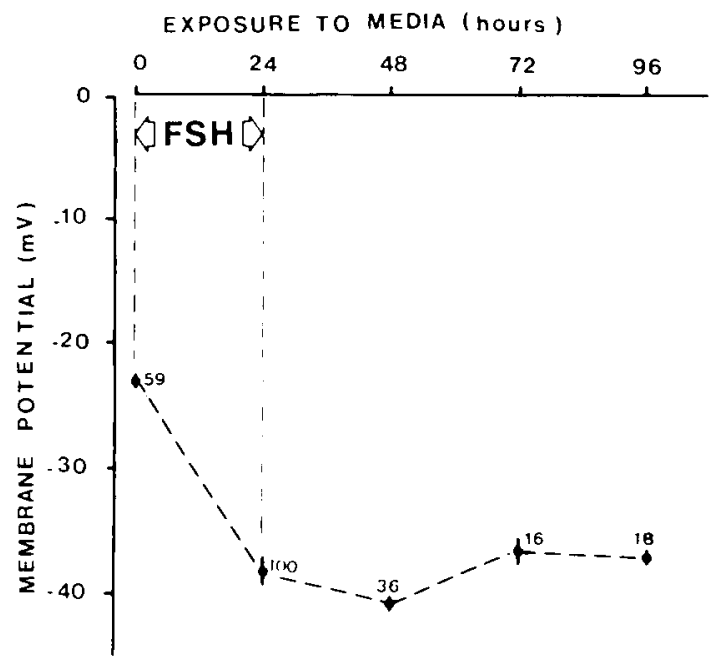

FIG. 1. - Recovery period of FSH-induced hyperpolarization of Sertoli cells after 24- $h$ exposure to $2.9 \mu \mathrm{g} / \mathrm{m} / \mathrm{NIAMDD}{ }_{0} F S H . S_{16}$.

The cells were isolated from 17-day-old rats by collagenase and pancreatin treatments, then cultured for 3 to 7 days in RPMI medium. The cells were exposed to FSH for 1 day then incubated in the control medium which was changed every day. The membrane potential of unstimulated cells was increased by FSH then remained constant in the control medium.

Values are expressed as means \pm SEM ( $\mathrm{n}=$ number of impaled cells). 
The use of inhibitors and ionic replacements have proven that FSH effects on the membrane are related (1) to the activation of the $\mathrm{Na} / \mathrm{k}$ pump (blocked by ouabain) ; (2) to an increase in the $\mathrm{Na}$ / $\mathrm{Ca}$ influx (blocked by cobalt). This, in turn, regulates intracellular concentration and the exit of potassium from the cell by a K channel (blocked with quinidine) (Joffre and Roche, 1988). These results correspond closely with radioisotopic and chemical data concerning the exocrine function of Sertoli cells obtained in whole seminiferous tubules (see review: Waites and Gladwell, 1982).

The present results show that the intracellular effects of $\mathrm{FSH}$, through a cAMP-dependent mechanism, are not reversed by exposure to a FSH-free medium, suggesting an initial effect of $\mathrm{FSH}$ on the junctional complex between Sertoli cells and then its insensitivity to this hormone.

Studies of electrical coupling between cells have been carried out on several exocrine glands. They show that messengers affect the functional state of the gap junctions between neighboring cells. To test FSH effects on electrical coupling between Sertoli cells (related to gap junctions), we used three methods:

1) direct evaluation of coupling using two microelectrodes (Roche, Joffre and Deleze, preliminary results). The degree of coupling appeared to vary greatly from cell to cell in the same culture as previously observed by Eusebi et al. (1985). Such a situation precluded the use of this method to determine FSH effects on the junctional complex;

2) the electrophysiological properties of cells and their electrical coupling can be recorded by the patch clamp method. Unfortunately, the dissociated cells formed an epithelial structure, after 2 -day culture, which precluded the use of the method. Therefore, a new cellular model must be used to directly measure the intra and intracellular effects of FSH on Sertoli cells by the patch clamp technique ;

3) many treatments known to affect electrical coupling of cells modify the recordings obtained by the intracellular microelectrode technique (Petersen, 1980 ; Loewenstein, 1981 ; Poisner and Trifaró, 1985) so we measured the membrane potential of cells exposed to different uncoupling treatments (Loewenstein, 1981). In several tissues intracellular calcium concentration is known to control junctional coupling between neighboring cells. Intracellular coupling may be reduced either by increasing the intracellular calcium to relatively high levels or by reducing extracellular calcium with EGTA. All the treatments which involve an increase in intracellular calcium, i.e. calcium ionophores A 23187 (fig. 2), heptanol or uncouplers of oxidative phosphorylation as carbonylcyanid-m-chlorophenylhydrazone ( $\mathrm{CCmP}$ ), entirely suppress $\mathrm{FSH}$-induced hyperpolarization and slightly depolarize unstimulated cells. Similar results are obtained with a 0 calcium solution containing EGTA. These effects are either partially or totally reversed by a recovery period in a drug-free medium. Similar results are recorded on cells exposed to trypsin prior to mechanical dispersion. But in the latter case, cell hyperpolarization is only found again after new exposure to FSH (Roche and Joffre, 1988).

Membrane depolarization is not necessarily related to cell uncoupling and, conversely, cell uncoupling does not necessarily induce cellular depolarization. Nevertheless, in many cases electrical uncoupling is associated with cellular 
depolarization (Loewenstein, 1981). Therefore, the present experiments were consistent with the suggestion that Sertoli cells in monolayer culture exposed to $\mathrm{FSH}$ are electricallycoupled, and that this coupling is much more important than that of unstimulated cells. FSH seems to increase the number and/or the conductance of the gap junctions between neighboring Sertoli cells in monolayer culture. Such an effect of FSH was observed previously on the ovarian follicle (Burghardt and Anderson, 1981). Data obtained with CAMP suggest that this cyclic nucleotide is involved in this process, as in many structures (Loewenstein, 1981 ; Hertzberg, Lawrence and Gilula, 1981 ; Spray and Bennett, 1985).

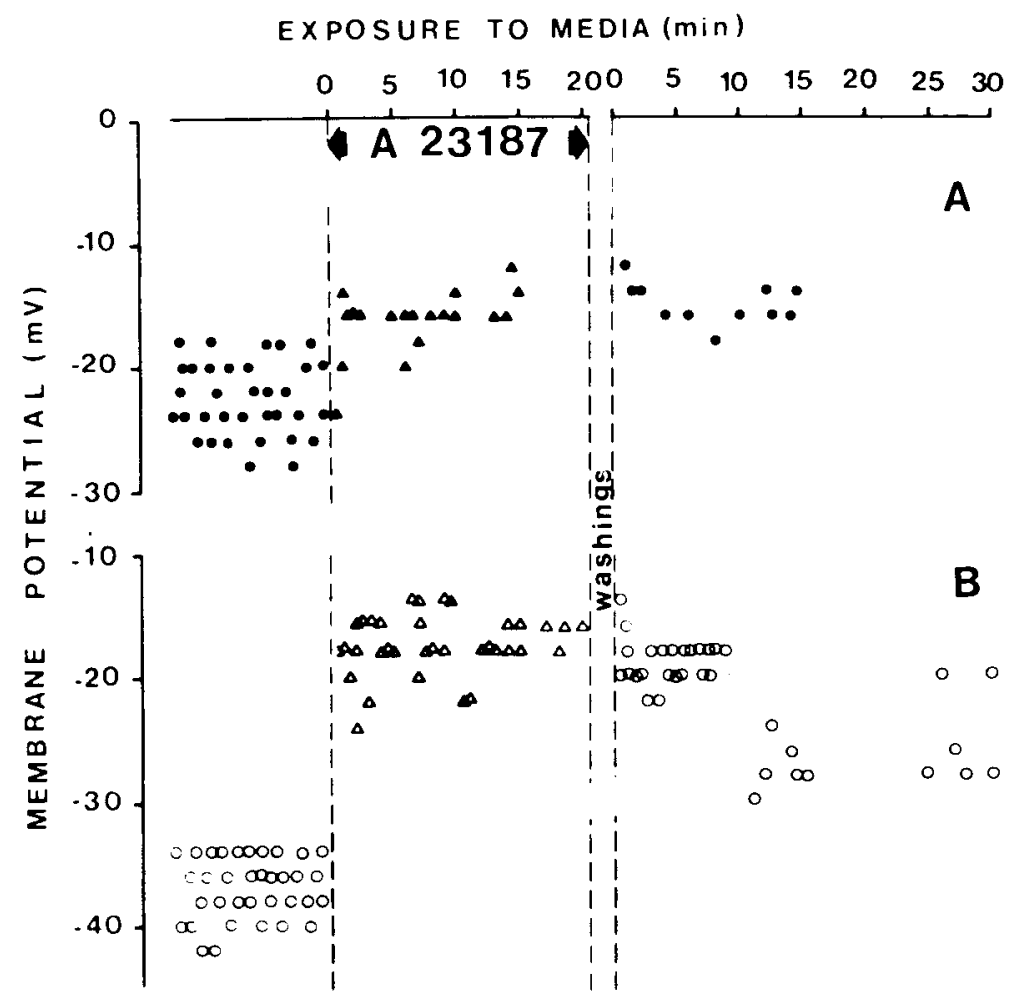

FIG. 2. - Effects of an uncoupling drug on the membrane potential of unstimulated (A) and FSH-stimulated cells (B).

The calcium ionophore $A 23187$ (stock solution in methanol) was dissolved at $5 \cdot 10^{-6} \mathrm{M}$ in electrophysiological medium. The membrane potential of unstimulated cells was slightly decreased by $A 23187(-16.4 \pm 0.6(n=10)$ as against $-22.5 \pm 0.5(n=33))$ while the membrane potential was largely decreased $(-17.6 \pm 0.4(n=35)$ as against $-33.6 \pm 0.4$ $(n=44)$ ) when the cell was stimulated by FSH. This effect was partially reversed by a recovery period in control medium. 


\section{Effects of hCG on mature Leydig cells from rat testis.}

Intracellular microelectrode studies. - Using the intracellular microelectrode method, we previously observed that the electrophysiological characteristics of Leydig cells from rat testis were similar to those of fibroblastes and macrophages ; all three cell types are of the same mesenchymal origin and present in the interstitial tissue of the testis. However, unlike fibroblastes and macrophages, Leydig cells do not trigger an hyperpolarizing oscillation in steady state by mechanical or electrical stimuli (Joffre et al., 1984a). The membrane potential of unstimulated cells $(-25.1 \pm 0.6 \mathrm{mV})$ is mainly dependent on external potassium, only slightly dependent on external sodium and not directly dependent on external calcium. The cell membrane is permeable to chloride ions which are passively distributed according to membrane potential. This potential is chiefly determined by calcium-activated potassium permeability and only slightly by $\mathrm{Na} / \mathrm{K}$ pump activity (Joffre et al., 1984b).

When Leydig cells were incubated in medium containing hCG $(300 \mathrm{mlU} / \mathrm{ml})$, the membrane potential was decreased. This depolarization occurred after 2-min exposure to hCG $(150 \mathrm{mlU} / \mathrm{ml})$. The effect was mimicked by dBcAMP. It was not abolished by verapamil, a calcium channel blocker, suggesting that this decrease was not related to calcium influx but to blockade of calcium-activated potassium permeability (Joffre et al., 1984b).

Patch clamp studies. - Patch clamp recordings were carried out on freshly isolated cells or after a short culture period. The success of the method depends on the formation of the seals between pipettes and membranes, which in turn depends on the cleanness of the membrane surface and the collagenase procedure. Most seals were obtained on spherical Leydig cells.

Whole-cell configuration can be used to estimate membrane potential. This potential averaged $-30.7 \pm 2.4 \mathrm{mV}$, which is higher than the value determined with the microelectrode method. Such a result is related to a leak around the microelectrode which did not occur in the patch clamp method. When membrane currents were evoked by applying a depolarizing voltage step, a potassium current was recorded if the cells were dialyzed with low $\left(10^{-8}-10^{-9} \mathrm{M}\right)$ calcium media (fig. 3A). This current was decreased by tetraethylammonium, an inhibitor of the potassium channel. When the calcium concentration was increased to $10^{-7}$ $-10^{-6} \mathrm{M}$, a second current was triggered (fig. $3 \mathrm{~B}$ ) which was mainly carried by chloride since external exposure to glutamate (an ion which does not flow through the chloride channel) decreased this current (Duchatelle and Joffre, 1987). A chloride channel was observed in the outside-out patch configuration (fig. 4 ; see legend of the experimental procedure). It was selective of the chloride ion and presented a specific conductance of $160 \mathrm{pS}$.

With the whole-cell recording method, the membrane potential of hCGstimulated cells was similar to that of unstimulated cells. Such a result cannot be explained at present.

On the other hand, responses to different intracellular calcium concentrations were not modified on the hCG-stimulated cells, suggesting the absence of direct control of the channels by this hormone. However when a cell was dialyzed with 

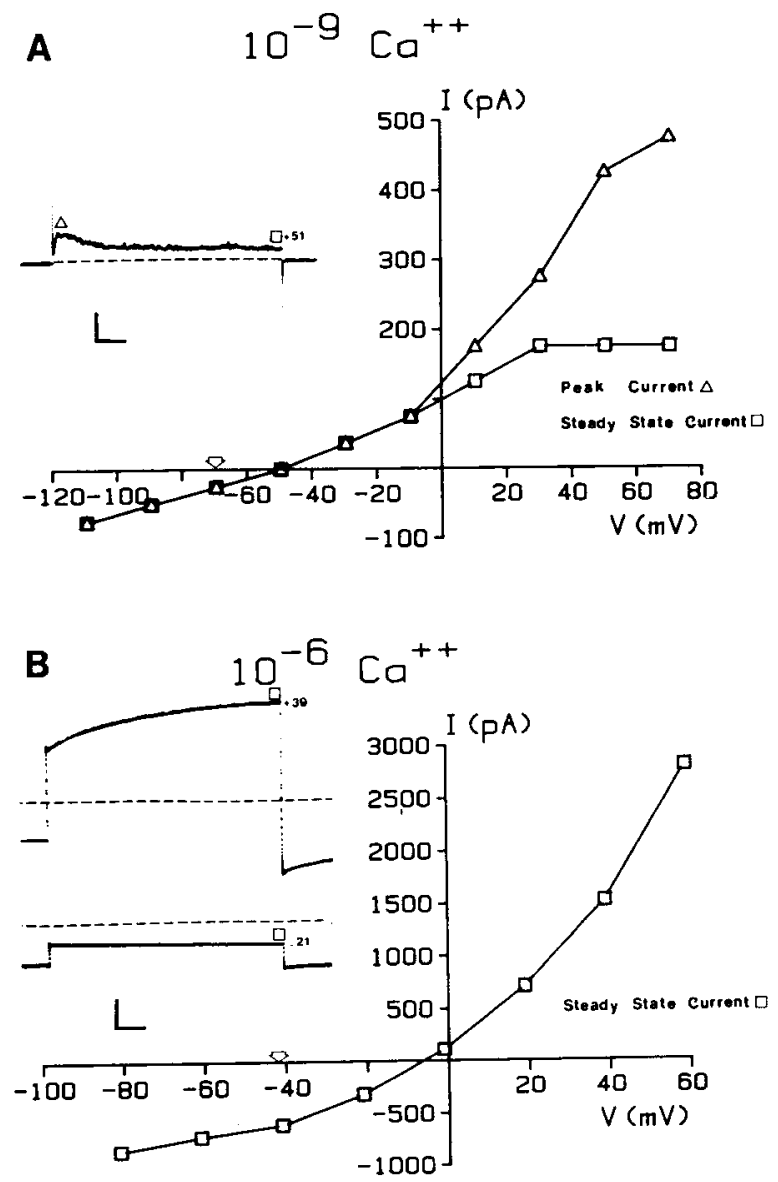

FIG. 3. - Ionic currents triggered in the membrane of Leydig cells in response to depolarizing voltage pulses applied from a holding potential (arrows) to test the potential indicated near the recordings. Dashed line : zero current levels.

Calibrations : current : $500 \mathrm{pA}$, time : $\mathbf{5 0} \mathrm{ms}$.

Curves: Current (I)-voltage (V) relationships of the two cells.

$\mathrm{A}$ : with a low-calcium micropipette solution $\left(10^{-9} \mathrm{M}: 0 \mathrm{Cl}_{2} \mathrm{Ca}+0.5 \mathrm{mM}\right.$ EGTA $)$, a depolarizing voltage step elicited a small outward current with a peak value.

$B$ : with a high-calcium micropipette solution $\left(10^{-6} \mathrm{M}: 10 \mathrm{mM} \mathrm{Ca}+\mathrm{mM}\right.$ EGTA), a depolarizing voltage step elicited a long-lasting current change towards a steady-state value, followed by a tail current returning to the holding potential. 
A

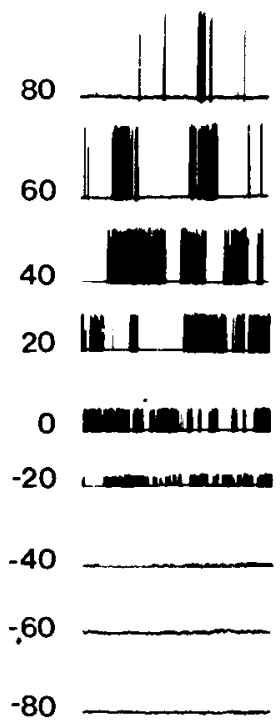

$10 \mathrm{pA} \frac{}{12 \mathrm{sec}}$

C

\section{B}
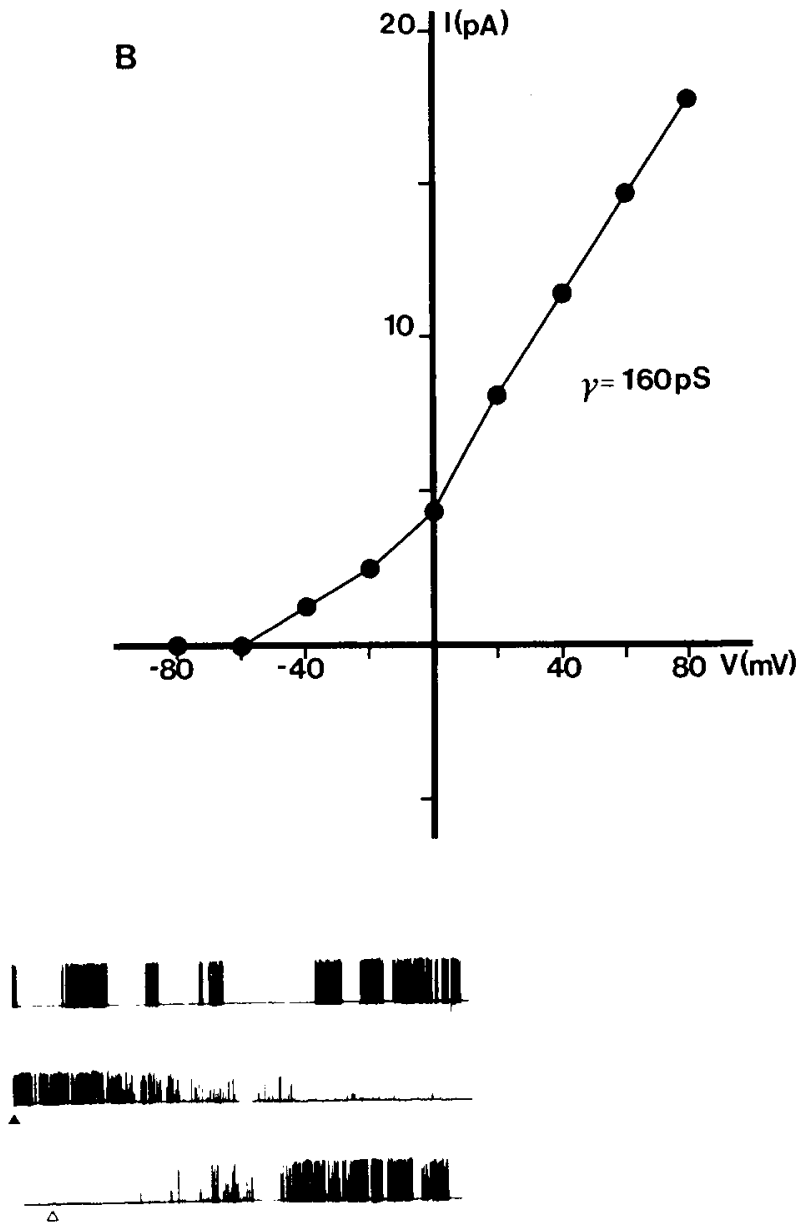

$10 \mathrm{pA}$

$12 \mathrm{sec}$

FIG. 4. - A : Current recordings obtained at different transpatch potentials indicated. These recordings were obtained from an outside out patch which was bathed by standard external solution (see text) in outside and by a glutamate solution in inside (128 mM K glutamate, $12 \mathrm{mM}$ $\mathrm{KCl}, 0.5 \mathrm{mM}$ EGTA, $0.2 \mathrm{mM}$ ATP). The current which flowed through the channel was always outward.

B : Plot of the single-channel current amplitude against the transpatch potential from the same experiment. The relationship was linear during depolarization although there were derivations at hyperpolarized potentials. For potentials of more than $-60 \mathrm{mV}$ no current was measured, showing that the channel did not conduct glutamate from inside to outside. The linear portion of the line gave a conductance of $160 \mathrm{pS}$.

C: Effect of external glutamate on the conductance of C/ channel. Exposure of the outside to glutamate solution ( $\mathbf{\Delta}$ ) suppressed the current flowing through the channel. After a recovery period in standard solution $(\triangle)$ the current reappeared, showing the $\mathrm{Cl}$ selectivity of this channel. Value of transpatch potential $=+20 \mathrm{mV}$. 

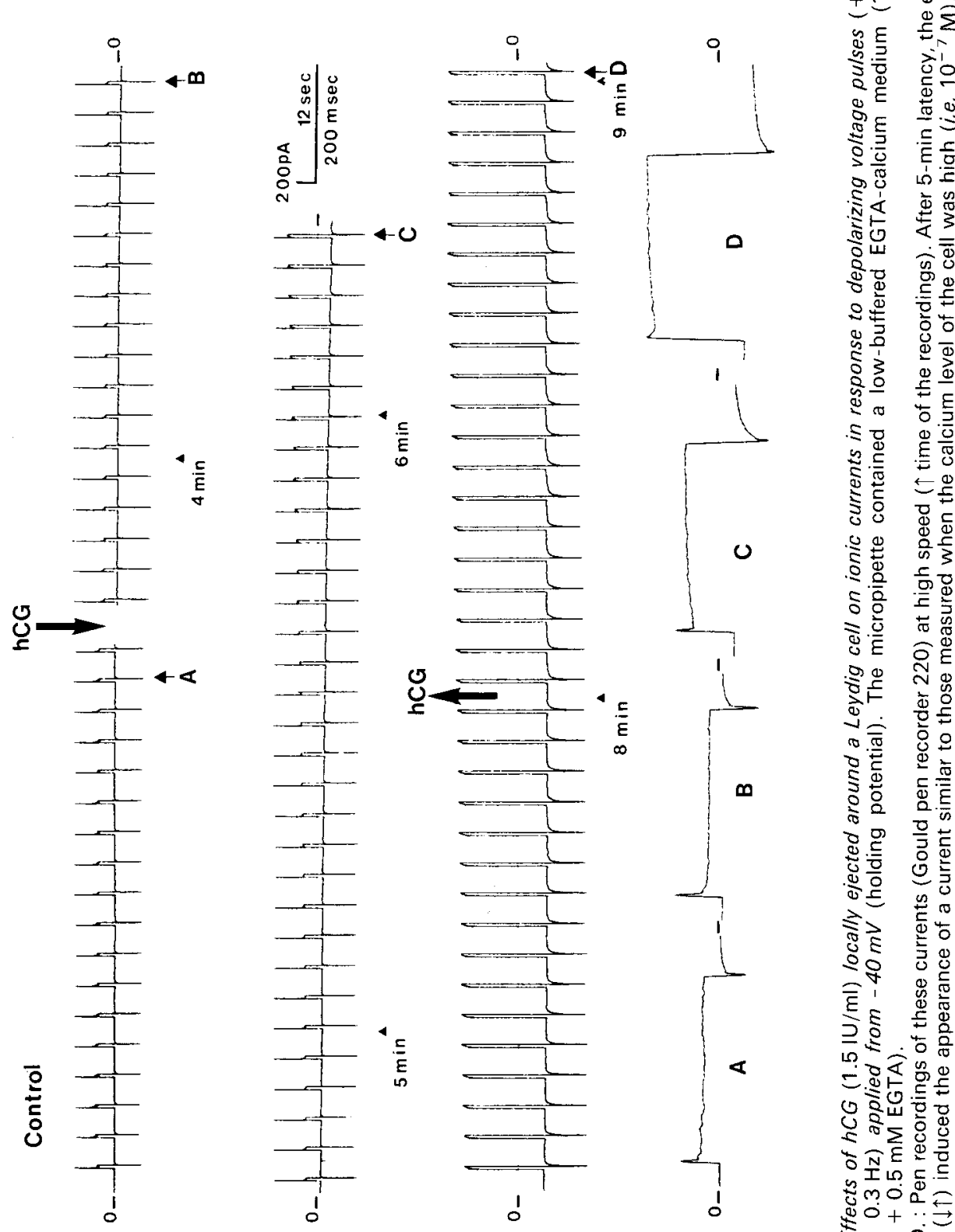

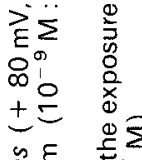
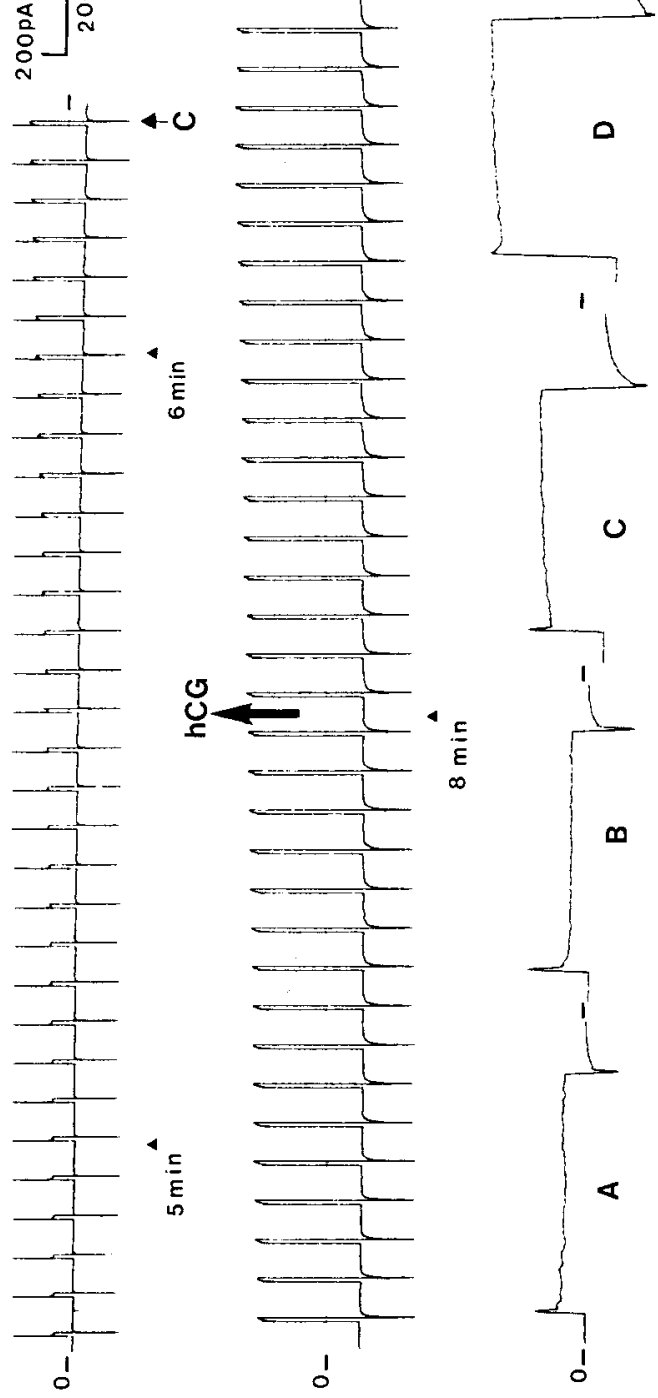

을

बे

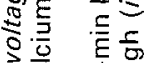

o

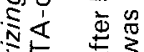

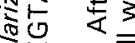

넝

ब웜

원

फे

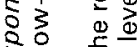

ه

$\leqslant$ 인

ڤ. है

ญ气

o d

원

음 可品

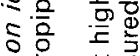

与.

छ $\overparen{्}$

윋 ฟ

वै 㝴号

尚

ఏ吉

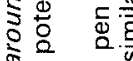

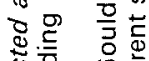

응 능

نE

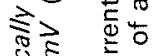

ऽह ड

है

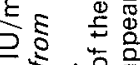
$10=-0 \frac{0}{10}$ 원요 0 㟧 U 2

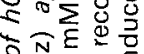
○กำ जั 过 $+\cdots \leftrightarrows$ का लD | E⿱一兀)U เে 믄 
a low-buffered EGTA-calcium medium $\left(10^{-9} \mathrm{M}\right)$, then exposed to hCG locally ejected around the cell, the membrane currents were modified. Such results are consistent with the notion that the hormone increases intracellular calcium. This increase is a rapid event since modifications of the currents were measured after 5-6 min exposure to the hormone (preliminary results) (fig. 5).

Reçu en octobre 1987. Accepté en avril 1988.

Acknowledgements. - This work was supported by grants from C.N.R.S. and I.N.R.A. [ATP-I.N.R.A. "Hormones hypophysaires et fonction de reproduction chez les Vertébrés " (1985)].

Résumé. Etudes électrophysiologiques du mécanisme d'action des gonadotropines sur les cellules de Leydig et de Sertoli du testicule de rat.

Par la technique des microélectrodes intracellullaires, nous avons pu montrer que FSH provoque l'augmentation du potentiel de membrane de la cellule de Sertoli en culture, isolée du testicule de rats âgés de 17 jours. Cette hyperpolarisation est liée à l'activation d'une pompe $\mathrm{Na} / \mathrm{K}$ ainsi qu'aux augmentations d'un influx calcico-sodique et d'un efflux potassique. Cet effet est irréversible et se produit par l'intermédiaire d'un mécanisme AMPc-dépendant. D'autres résultats suggèrent un effet initial de $\mathrm{FSH}$ sur le complexe jonctionnel intercellulaire, puis sa dépendance calcique.

Par la méthode des voltages imposés à des membranes de cellules entières nous avons étudié les courants transmembranaires de cellules de Leydig isolées du testicule de rats adultes. Deux types de courants sont évoqués par des impulsions dépolarisantes: un courant potassique, enregistré lorsque les cellules sont dialysées avec un milieu faiblement concentré en calcium $\left(10^{-9}-10^{-8} \mathrm{M}\right)$ et un courant chlore, enregistré lorsque les cellules sont dialysées avec un milieu riche en calcium $\left(10^{-7}-10^{-6} \mathrm{M}\right)$. Cette réponse à une augmentation du taux intracellulaire de calcium n'est pas modifiée par hCG; mais cette hormone induit le changement précoce du courant potassium en courant chlore lorsque les celfules sont dialysées avec un milieu faible calcium-faible tampon EGTA. Ceci suggère que la stimulation par hCG implique le blocage du courant potassique et l'activation d'un courant chlore, par un accroissement du calcium cytosolique.

\section{References}

BERNIER M., SAEZ J. M., 1985. Evidence de deux mécanismes impliqués dans le phénomène de la régulation négative des récepteurs à l'hCG-LH. Développements récents de l'endocrinologie du testicule. In SAEZ J. M., FOREST M. G., DAZORT A., BERTRAND J. Colloque INSERM, 123, 239-244.

BURGHARDT R. C., ANDERSON E., 1981. Hormonal modulation of gap junctions in rat ovarian follicles. Cell. Tissue Res., 214, 181-193.

CUTHBERT A. W., WONG P. Y. D., 1975. Intracellular potentials in cells of the seminiferous tubules of rats. J. Physiol. London, 248, 171-181.

DUCHATELLE P., JOFFRE M., 1987. Ca-dependent chloride and potassium currents in rat Leydig cells. FEBS Letters, 217, $11-15$.

EUSEBI F., GRASSI F., FRAMICO G., DOLCI S., CONTI M., STEFANINI M., 1985. Cell-to-cell communication on cultured Sertoli cells. Pflügers Archiv, 404, 382-384.

HERTZBERG E. L., LAWRENCE T. S., GILULA N. B., 1981. Gap junctional communication. Annu. Rev. Physiol., 43, 479-491. 
JOFFRE M., MOLLARD P., REGONDAUD P., ALIX J., POINDESSAULT J. P., MALASSINÉ A., GARGOUÏL Y. M., 1984a. Electrophysiological study of single Leydig cells freshly isolated from rat testis. I. Technical approach and recordings of the membrane potential in standard solution. Pflügers Archiv, 401, 239-245.

JOFFRE M., MOLLARD P., RÉGONDAUD P., GARGOUÏL Y. M., 1984b. Electrophysiological study of single Leydig cells freshly isolated from rat testis. II. Effects of ionic replacements, inhibitors and human chorionic gonadotropin on a calcium-activated potassium permeability. Pflügers Archiv, 401, 246-253.

JOFFRE M., ROCHE A., 1988. Follicle stimulating hormone induces hyperpolarization of immature rat Sertoli cells in monolayer culture. J. Physiol. London, 400, 481-499.

LOEWENSTEIN W. R., 1981. Junctional intercellular communication : the cell-to-cell membrane channel. Physiol. Rev., 61, 829-913.

OZAWA S., SAND O., 1986. Electrophysiology of excitable endocrine cells. Physiol. Rev., 66, 887-952.

PETERSEN O. H., 1980. The electrophysiology of gland cells. Acad. Press, London.

POISNER A. M., TRIFARO J. M., 1985. The electrophysiology of the secretory cell. The secretory process., vol. 2, Elsevier, Amsterdam.

ROCHE A., JOFFRE M., 1988. Effect of uncoupling treatments on FSH-induced hyperpolarization of Sertoli cells from rat testis in monolayer culture. Submitted to J. Reprod. Fertility.

SAEZ J. M., FOREST M. G., DAZORT A., BERTRAND J., 1985. Développements récents de l'endocrinologie du testicule. Colloque INSERM, vol. 123.

SAKMANN B., NEHER E., 1983. Single channel recordings. Plenum Press, New York.

SOLARI A., FRITZ I. B., 1978. The ultrastructure of immature Sertoli cells. Maturation-like changes during culture and the maintenance of mitotic potentiality. Biol. Reprod., 18, 329-345.

SPRAY D. C., BENNETT M. V. L., 1985. Physiology and pharmacology of gap junctions. Annu. Rev. Physiol., 47, 281-303.

VERHOEVEN G., DIERICKX P., DE MOOR P., 1979. Stimulation effect of neurotransmitters on the aromatization of testosterone by Sertoli cells enriched cultures. Mol. cell. Endocrinol.,13, $241-245$.

WAITES G. M. H., GLADWELL R. T., 1982. Physiological significance of fluid secretion in the testis and blood testis barrier. Physiol. Rev., 62, 624-671. 